\title{
Agroforestry Benefits and Challenges for Adoption in Europe and Beyond
}

\author{
Maya Sollen-Norrlin ${ }^{1}$, Bhim Bahadur Ghaley ${ }^{2}$ and Naomi Laura Jane Rintoul ${ }^{1, *}$ \\ 1 School of Psychology and Life Sciences, Canterbury Christ Church University, Canterbury CT1 1TE, UK; \\ maya.sollen@gmail.com \\ 2 Department of Plant and Environmental Sciences, Faculty of Science, University of Copenhagen, \\ 2630 Taastrup, Denmark; bbg@plen.ku.dk \\ * Correspondence: naomi.rintoul@canterbury.ac.uk
}

Received: 3 July 2020; Accepted: 18 August 2020; Published: 27 August 2020

check for updates

\begin{abstract}
Soil degradation is a global concern, decreasing the soil's ability to perform a multitude of functions. In Europe, one of the leading causes of soil degradation is unsustainable agricultural practices. Hence, there is a need to explore alternative production systems for enhanced agronomic productivity and environmental performance, such as agroforestry systems (AFS). Given this, the objective of the study is to enumerate the major benefits and challenges in the adoption of AFS. AFS can improve agronomic productivity, carbon sequestration, nutrient cycling, soil biodiversity, water retention, and pollination. Furthermore, they can reduce soil erosion and incidence of fire and provide recreational and cultural benefits. There are several challenges to the adoption and uptake of AFS in Europe, including high costs for implementation, lack of financial incentives, limited AFS product marketing, lack of education, awareness, and field demonstrations. Policies for financial incentives such as subsidies and payments for ecosystem services provided by AFS must be introduced or amended. Awareness of AFS products must be increased for consumers through appropriate marketing strategies, and landowners need more opportunities for education on how to successfully manage diverse, economically viable AFS. Finally, field-based evidence is required for informed decision-making by farmers, advisory services, and policy-making bodies.
\end{abstract}

Keywords: agroforestry; agronomic productivity; ecosystem services; agroecology; farmland management; sustainability

\section{Introduction}

Soil degradation is the "decline in soil quality or its capacity to produce economic goods or provide ecosystem services" [1] (p. 709). Soil degradation can result in soil compaction, salinity, nutrient loss, reduction in biodiversity, or contamination leading to unproductive soils, dependent on the crops grown, soil type, and management in an agro-ecosystem. Agro-ecosystems provide provisioning, regulating, supporting, and cultural ecosystem services, and amongst these services, provisioning services like food, fodder, fibre, and fuelwood have economic values due to their marketable values [2]. However, it is a challenge to add economic values to regulating, supporting, and cultural ecosystem services as the goods and services are non-marketable and the importance of these ecosystem services are location-specific, adding another complexity to valuation.

Soil degradation is a global concern that is most prominent in the tropics and subtropics. Soil degradation is a concern in Europe as there is a need to maintain the multifunctional role of soils for primary productivity, carbon sequestration, nutrient storage and regulation, water storage and cycling, and habitat for biodiversity [3]. The leading cause of soil degradation in Europe is the intensive conventional arable production system, where losses of up to $300 \mathrm{Tg} C\left(10^{12}\right)$ year $^{-1}$ is 
reported [4]. The use of mechanical tillage causes adverse effects on soil structure and enhances the decomposition process, leading to nutrient loss through leaching and volatilization and imbalances in nutrient supply [5]. Furthermore, the use of pesticides has adverse effects on soil biodiversity [6]. Given the challenges of soil degradation due to conventional intensive production systems, there is need for production systems that enhance agronomic productivity and environmental performance.

Agroforestry, the practice of integrating trees and shrubs with crops or livestock production [7], is one such potentially sustainable way of achieving healthier soils for increased agricultural production $[8,9]$ and environmental performance. Agroforestry systems (AFS) include silvoarable systems (combination of trees/shrubs with crops), silvopastoral (combination of trees with livestock), and agro-silvopastoral (combination of trees/shrubs with both crops and livestock), riparian buffer strips, and home gardens [10]. Besides provisioning services, viz., food, fodder, fibre, and fuelwood production, AFS provide several other ecosystem services, including regulation of nutrient cycling, carbon sequestration, habitat for biodiversity, erosion control, fire and flood control, and recreational and cultural services [11,12]. Hence, the objective of this study is to assess the beneficial effects of AFS on agronomic productivity, carbon sequestration, soil nutrient cycling, soil biodiversity, soil erosion and water retention, recreation and culture, fire and pollination, and to highlight the challenges faced in the adoption of AFS.

\section{Benefits of AFS}

\subsection{Agronomic Productivity}

The land equivalent ratio (LER) was first proposed by Mead and Willey [13] and is defined as the ratio of the area under sole cropping to the area under intercropping needed to give equal amounts of yield at the same management level [14]. It is the most common measure for comparing productivity in terms of biomass or other yields [15] and is a valuable tool to assess the production system when considering conversion of conventional agricultural land to AFS [16].

The evidence of higher productivity in agroforestry systems has been reported in different studies. The LER of a combined food and energy (CFE) production system in Denmark ranged from 1.14-1.34 [17], indicating that crop and tree yields produced in agroforestry required $14-34 \%$ less land or fewer resources in terms of light, water, nutrients, compared to monoculture. This is a significant advantage and provides avenues for ecological intensification to produce more with fewer inputs. A recent study investigated five agroforestry systems that differed in crop, tree, and grass species under diverse pedo-climatic zones and management regimes; LER values ranged between 1.36-2.00, demonstrating a higher productivity in a diversity of AFS [18]. Likewise, in the oldest and most well-documented agroforestry experimental site in Europe, silvoarable agroforestry systems had LER estimates of 1.3-1.6 [16]. Other studies have used modelling to determine the productivity of different agricultural systems. Over 30 years, it was estimated that 1.28 ha of separate forestry and arable systems would be needed to produce the crop and timber yields obtained in a silvoarable system [19]. In a study of 14 different agroforestry practices by Sereke et al. [20], the AFS were commonly more productive than separate forestry or arable systems ( 12 out of the 14 options, land equivalent ratio $=0.95-1.30$ ).

Despite numerous studies demonstrating the higher productivity of AFS, these results contradict the views of farmers, who see AFS as unproductive and thus as financially unviable [20]. This view is reiterated in many other papers assessing farmers' opinions of barriers to AFS adoption, where farmers are often concerned with the financial risk $[7,19,21,22]$. Given that there is a need to increase food production significantly by 2050 [23], high-yielding agroforestry provides a viable option to contribute to the yield increase to meet the increase in food demand due to population growth and changes in food consumption patterns. 


\subsection{Soil Carbon Sequestration}

Soil represents a large pool of carbon (C), consisting of about $1550 \mathrm{Gt}$ of soil organic carbon (SOC) and $950 \mathrm{Gt}$ of soil inorganic carbon (SIC) [24]. Soil organic carbon occurs mostly as a fraction of organic matter $(\mathrm{OM})$, and its levels in soils are determined by a dynamic balance of inputs and outputs [24]. Carbon sequestration occurs when the $C$ input to soil is higher than the $C$ release [25]. Agricultural soils in Europe generally act as carbon sources, but have a high potential to become carbon sinks with changes in land management [24]. Because soil organic matter (SOM) contains 50-58\% carbon, the loss of OM from soils in conventional agriculture contributes to $C$ sources [26]. Agroforestry systems add significant amounts of SOM, resulting in multiple benefits such as improved soil moisture retention, greater soil nitrogen mineralisation, and, importantly, increased carbon sequestration, and thus climate change mitigation [27].

A field experiment of 17 arable agroforestry fields in Belgium revealed that trees increased carbon by 5.3 ton organic carbon (OC) ha ${ }^{-1}$ in the plough layer, compared to treeless control plots [28]. Similarly, a Canadian field experiment recorded an increase in SOC of 6.2 ton OC ha ${ }^{-1}$ in the top 0-20 $\mathrm{cm}$ of soil after 21 years of intercropping with poplar, compared to arable cropping without trees [29]. Inclusion of woody crops, viz., willow, can add up to $103 \mathrm{Mg}^{\text {carbon } \mathrm{ha}^{-1}}$ [30], inclusive of aboveground, belowground, and soil organic carbon. Kay et al. [31] identified priority areas across Europe where the implementation of agroforestry could be particularly effective and examined the impact of AFS on soil carbon. They determined that conversion of arable systems to AFS within these priority areas could lead to the sequestration of 2.1 to 63.9 million $\mathrm{t} \mathrm{C} \mathrm{a}^{-1}$, depending on the type of agroforestry, which corresponds to $1.4 \%$ to $43.4 \%$ of European agricultural greenhouse gas (GHG) emissions. Aertsens, De Nocker and Gobin [25] estimated that implementation of agroforestry on arable land in the EU has the potential to sequester $2.75 \mathrm{tC} \mathrm{ha}^{-1}$ year ${ }^{-1}$ and a further $2.75 \mathrm{tC} \mathrm{ha}^{-1}$ year $^{-1}$ on pasture land. This is 5-10 times the $C$ sequestration potential of conventional agriculture [25]. Comparing the environmental footprint in terms of global warming potential, acidification, and eutrophication, agroforestry systems were found to be more environmentally friendly compared to the conventional arable production system [18].

Alley cropping is a common agroforestry practice in Europe [32]. In this system, crops are grown in strips in-between rows of trees and shrubs [33]. This is distinctly different from conventional farming systems where one plant species is grown as a monoculture [25]. In silvopastoral systems, livestock is grazed on grasslands with trees growing on them, compared to conventional pastures consisting of grassland monocultures [34]. These AFS increase carbon sequestration in several ways, compared to the conventional systems. Firstly, the woody biomass of trees is $46-51 \% \mathrm{C}$ and thus represents a main pathway of $C$ accumulation [35]. Deposition of vegetation onto the soil through litter fall and crop residues leads to increased incorporation of $\mathrm{C}$ as OM into the soil [35,36], and enhanced root production increases $C$ in the soil [37]. Indeed, roots represent a more important component of $C$ sequestration in AFS in deep soil horizons than herbaceous understory and crop plants, and thus can relocate $\mathrm{C}$ to below the plough layer and protect it from oxidation [37].

\subsection{Nutrient Cycling}

Nutrients in AFS generally are provided from prunings and litter fall from the trees, making the nutrients available for the crops in the alley [38]. However, in some AFS synthetic fertilisers are also used [39]. Nutrient availability and cycling have been shown to be greater and more efficient in AFS, compared to conventional agro-ecosystems [40,41]. This can be attributed to several different processes: the incorporation of nitrogen-fixing tree species or the use of leguminous crops in crop rotation or as cover crops leads to increased stocks of nitrogen (N) [42]. For example, 650 woody species in temperate regions can fix nitrogen from the atmosphere, and $32-58 \%$ of the total nitrogen required for the alley-cropped maize came from the nitrogen fixation by the adjacent alder trees [43]. In a combined food and energy system in Denmark, mineralized nitrogen was $108 \mathrm{~kg} \mathrm{~N} \mathrm{ha}^{-1}$ year $^{-1}$ for AFS, compared to $64 \mathrm{~kg} \mathrm{~N} \mathrm{ha}^{-1}$ year $^{-1}$ in a conventional wheat production system [2]. In addition, 
Pardon et al. [28] recorded increased concentrations of nutrients in AFS compared to treeless control plots, where concentrations were greater by $35.5 \mathrm{mg} \mathrm{kg} \mathrm{dm}^{-1}, 28.8 \mathrm{mg} \mathrm{kg} \mathrm{dm}^{-1}, 16.2 \mathrm{mg} \mathrm{kg} \mathrm{dm}^{-1}$, and $5 \mathrm{mg} \mathrm{kg} \mathrm{dm}^{-1}$ for $\mathrm{K}, \mathrm{P}, \mathrm{Mg}$, and $\mathrm{NA}$, respectively.

In AFS, biomass production of the trees is faster than in forests as there is less competition amongst the trees [25]. This rapidly produced biomass can then be recycled back into the system, which improves SOM content and nutrient recycling [40]. Tree roots can reach and utilise nutrients that have leached to deep soil layers that crop roots cannot reach [40]. These nutrients are then recycled into the system through leaf litter and turnover of fine roots [40]. Thus, agroforestry has the potential to improve soil fertility through improved nutrient cycling and retention $[25,40,41]$. For example, the leaf litter from adjacent poplar trees in agroforestry systems doubled the availability of nitrogen in soils for uptake by crops in the alleys to $7 \mathrm{~kg} \mathrm{~N} \mathrm{ha}^{-1}$ year $^{-1}$, compared to the soils located 8 to $11 \mathrm{~m}$ away from the trees [44]. Trees can also add significant nitrogen by intercepting rainfall through stemflow (rainfall intercepted by leaves and branches) and throughfall (rainwater intercepted by the canopy) to the tune of 15.22 and $10.99 \mathrm{~kg} \mathrm{~N} \mathrm{ha}^{-1} \mathrm{yr}^{-1}$ in hybrid poplar and silver maple tree systems, respectively [45].

Despite the opportunities that AFS present, there is a great deal of variability amongst different types of AFS in different contexts in terms of species, soil type, and other land-use conditions [46]. The net productivity of any agroforestry system is the result of interactions, negative and positive, between the components in the system [43]. In fact, some long-term yields may not differ between AFS and monoculture systems [47]. If all plant species in the system have the same requirements over time and space for the same resource (water, nutrients, light), they will compete with each other [43], and this can result in reduced yields [48]. For example, shading by trees can have negative impacts on crops as sub-optimal light availability can induce stress responses [49]. However, if the different species in the system use different resources at different temporal and spatial scales, they can instead improve each other's environment and facilitate growth $[43,49]$. Therefore, selection of tree and crop species that have different resource requirements is an important factor when maximising the efficiency of the AFS $[46,50]$. The water-retaining properties of the soil will also impact the degree of competition for water in the system, with more competition in free-draining soils and vice versa [43]. Further, different management practices, such as pruning, root cutting, and distance between and orientation of tree rows, as well as whether fertilizers are added or not, all have an impact on the interactive outcome of the species in the system $[38,39,42,43,49,50]$.

\subsection{Soil Biodiversity}

Soils are incredibly diverse: $1 \mathrm{~g}$ of soil has been estimated to contain 1 billion bacteria from tens of thousands of taxa, $200 \mathrm{~m}$ of fungal hyphae, and a vast variety of nematodes, mites, earthworms, and arthropods [51]. Soil organisms can be grouped by their ecological function; they are classed as decomposers, nutrient transformers, ecosystem engineers, and bio-controllers [52-54]. These functional assemblages contribute to four aggregated ecosystem functions: carbon transformations, nutrient cycling, soil structure maintenance, and population regulation, which through a variety of soil-based delivery processes generate and sustain soil health [55]. The diversity of soil organisms due to differences in litter quality and quantity results in a diversity of enzymes and enzymatic activity, supporting the critical soil functions of organic matter breakdown, nutrient availability, and recycling [56,57]. Agroforestry enhances the growth of arbuscular mycorrhizal fungi, which enhances litter decomposition, resulting in enhanced plant-available nutrients, and such positive effects have been demonstrated in field studies [58,59]. Marsden et al. [60] collated the results from 62 publications in order to examine the effect of agroforestry on soil fauna abundance and/or diversity in temperate climates. Of the papers that examined AFS compared to arable systems, the effects of AFS were mostly positive ( $70 \%$ of the data sets), and only two studies found a negative impact of AFS on soil fauna biodiversity or abundance. Similarly, a meta-analysis by Torralba et al. [46] found an overall positive effect of agroforestry on biodiversity, although the benefits of AFS are context-related. However, studies that examined the 
abundance or diversity of specific groups of organisms provided clearer information on the impacts of AFS on the soil ecosystem.

Decomposers and nutrient transformers (e.g., microorganisms such as algae, bacteria, fungi, and microarthropods) play a key role in breaking down OM [53,61,62], which then releases nutrients and contributes to nutrient cycling $[53,63]$. They fragment decomposing litter and increase availability to microbes. The symbiotic relationship between nitrogen-fixing bacteria and some plants (mainly legumes and some tree species) is well established [64]. Co-operative microbial activities such as biological nitrogen fixation (BNF) processes can be exploited as a low-input biotechnology in sustainable AFS $[64,65]$. In addition to this, mycorrhizal fungi in the soil take up phosphorous-particularly in P-deficient soils-and recycle it back into the system [66-68]. The microbial biomass also represents the living part of SOM, and living microbial cells usually represent $1-5 \%$ of the total organic $C$ in soils [65]. Although a relatively small proportion of soil $C$, the microbial biomass $C$ still represents a global pool of about $23 \mathrm{Pg}$ [69]. Thus, it seems a likely assumption that the increased abundance of soil microbes in AFS contributes to increased C storage. The high input of OM to the soil in AFS also contributes to the diversity and abundance of microorganisms as OM provides an energy source for the microbes [62].

Ecosystem engineers (e.g., earthworms and ants) alter the physical structure and porosity of the soil by creating burrows, chambers, and castings, and influence nutrient and energy flow by ingesting organic matter and mixing with the soil $[52,53,70]$. In a combined food and energy system in Denmark, the earthworm count in shelter belts was $148 \mathrm{~m}^{-2}$, compared to $63 \mathrm{~m}^{-2}$ in a conventional barley production system [2]. In a study of 13 agroforestry sites in France, abundance and biomass of earthworms were higher in AFS than in control plots, as were the soil organic carbon stocks [64]. Similarly, a North American study found that earthworm density was higher within AFS than within monocultures [71].

Bio-controllers (e.g., microfauna and macrofauna such as nematodes and collembolans) act as herbivores or predate on other soil organisms, regulating the activity of the soil microbial community and thus affecting nutrient flow [52-54]. Intensified agriculture has been shown to be detrimental to soil biodiversity, and a higher diversity of soil microorganisms has been observed in AFS compared to conventional agriculture systems [40,41]. In addition, according to Barrios et al. [55], AFS had a higher abundance of earthworms, beetles, centipedes, millipedes, termites, ants, collembola, mites, and non-parasitic nematodes than monocultures; the only group that had a higher abundance in monoculture was parasitic nematodes. Thus, AFS can increase both abundance and diversity of soil biota. Similarly, Mupeyo et al. [72] found that AFS can reduce parasitic nematode fecundity and thus have a positive impact on livestock. Banerjee et al. [73] quantified bacterial $16 \mathrm{~S}$ ribosomal RNA (rRNA) genes in soil samples from AFS (woodland or hedgerows) and controls (either grassland or agricultural land) and found that there was a higher abundance of soil bacteria in AFS. In addition, Bainard et al. [66] found greater fungi richness in an agroforestry system than in a monocrop, and several taxa that were found in the AFS were not present in a monocrop system. However, AFS have been shown to increase in fungi-to-bacteria ratio [74,75], which suggests that AFS have varying effects on different groups of organisms.

Differences in soil biota diversity and abundance can be attributed partly to the increased plant diversity of AFS compared to monocultures in conventional systems as plant diversity is positively linked to soil microbial diversity [65]. For example, higher soil invertebrate diversity is found near the trees compared to the alleys, due to high diversity of leaf litter resulting in high organic matter accumulation [71]. In addition, AFS structural complexity may alter soil biota. For example, leaves intercept rainfall and transpire water taken up by roots, canopy cover provides shade, and pruned leaves and branches provide soil cover and nutrient inputs. This, in turn, affects the temperature, moisture, erosion, and nutrient content of the soil and indirectly affects the soil biota by "fostering conditions for increased biological activity" [55].

Torralba et al. [46] argued that this capacity of agroforestry to provide food, shelter, habitat, and other resources is one of the main reasons why many agroforestry areas are protected under the 
Natura 2000 Directive and are frequently recorded as High Nature Value farmlands. In addition, almost a quarter of the natural habitat types listed in Annex I of the Directive refer to silvopastures. The EU Commission's Europe 2020 strategy for a "resource efficient" Europe highlights the necessity of protecting, valuing, and restoring biodiversity and ecosystem services. However, more research on the effects of AFS is required; most studies focus on a single species or taxonomic group and many organisms are under-researched, particularly for temperate AFS [60].

\subsection{Soil Erosion and Water Retention}

AFS have several documented benefits to reduce the non-point source pollution of ground water and aquatic bodies due to reduction and filtration of surface runoff and enhanced infiltration into the soil to recharge the aquifers [76-78]. For example, a combined food and energy system recorded a water-holding capacity of $411 \mathrm{~mm} \mathrm{ha}^{-1}$ compared to a conventional wheat production system with a water-holding capacity of $283 \mathrm{~mm} \mathrm{ha}^{-1}$ [2]. Similarly, soil erosion prevention in a combined food and energy system was $3.3 \mathrm{Mg} \mathrm{ha}^{-1}$ year $^{-1}$, compared to equivalent soil loss due to soil erosion in conventional wheat production [2]. Agroforestry systems improve soil stability and prevent erosion through several processes. Increased ground cover from leaf litter and "tree mulch" intercepts rainfall, decreases the velocity of runoff water, reduces evapotranspiration, and limits soil crusting [79]. Increased OM improves the water-retaining properties and improves stability of the soil via improved aggregation and soil structure [79]. Moreover, trees and hedges provide a permeable barrier that slows down and intercepts water runoff [80]. Water infiltration rates were shown to be up to 60 times higher in areas planted with young trees than in adjacent grazed pastures [81]. Trees are also used to reduce wind erosion; globally, 300 million hectares of farmland are protected through windbreaks and shelterbelts [82]. In a meta-analysis by Torralba et al. [46] comparing agroforestry, conventional monoculture, and forested sites in Europe, agroforestry had a positive impact on erosion control.

Mulches, cover crops, and alley cropping help reduce soil temperature and soil loss [83]. For example, soil loss was reduced by up to $80 \%$ as a result of alley cropping [84]. Similarly, a study by Budelman [85] showed that mulches from trees or woody shrubs can decrease the soil temperature by up to $6.6^{\circ} \mathrm{C}$ and increase soil moisture content by up to $4.6 \%$. Soil evaporation is also regulated through shading [80]. The shading effect creates a humidity and temperature buffer that can protect the system from weather extremes such as torrential rain and heat waves $[86,87]$. Thus, AFS have the potential to both mitigate and adapt to increased rainfall and erosion and increasing temperatures, which justifies the argument for their wider implementation in the EU.

\subsection{Recreation and Culture}

Agroforestry systems can increase the diversity and improve the aesthetics of the landscape, which is more appealing for visitors compared to monoculture [12]. Agroforestry provides cultural services such as heritage value, recreation and ecotourism, knowledge systems, spiritual interactions, aesthetic values, and conserves species, habitats, and landscapes $[11,12,88]$. However, current measurements of cultural services are inadequate as they are the least researched ecosystem service category in agroforestry papers $[11,89]$.

AFS represent management practices based on local or indigenous knowledge that has evolved over time; they are the cultural, social, economic, and ecological heritage of the people $[89,90]$. Thus, Vera [91] stated that "it is only by knowing the wilderness that we can understand our cultural landscape". Recreation and ecotourism services are also provided by agroforestry sites on a regular basis for many people. Common examples are wild foraging, hunting, wildlife observation, walking or hiking, fishing, use of off-road recreation vehicles, horseback riding, and camping [92]. One survey found that $92.4 \%$ of participants could name at least one recreational service to household members or outsiders, and landowners were providing more than four of these services on average [92]. Moreover, McAdam et al. [12] noted that activities such as hunting, fishing, mountain biking, and horseback riding can diversify income for farmers, while the public can benefit from improved health and enjoyment 
from agroforestry through sports and wildlife watching. Similar opportunities were described for AFS in Italy by Pardini [93]. Well-known landscapes have a particularly high value for ecotourism, such as those in the New Forest in England, the cork oak systems of Spain and Portugal, or the wood pastures of the Alps [94].

Nature-based tourism is a rapidly expanding sector within tourism in Europe [95]. Thus, AFS can improve the rural economy in Europe if management through agritourism and local engagement is supported [96]. Since the aesthetic and recreation values are crucial to the success of ecotourism, there is a need for a market-based contractual mechanism to promote recreation and ecotourism that ensures a high aesthetic and recreational value [95]. Fortunately, some of the fundamental features of AFS have a high aesthetic value. For example, Dudek [97] created a valuation tool for forests based on their features that places a higher aesthetic value on forests with a high tree stand diversity, high diversity of flora in undergrowth, and more canopy layers. Thus, the promotion of AFS would go hand-in-hand with the promotion of forests that have a high recreation and ecotourism value; these systems are an important part of the culture and heritage in Europe, thus they should be preserved and sustainably managed [98].

\subsection{Pest and Disease Control}

It is estimated that $37 \%$ of USA crop yields are lost to pests [99] and $20-40 \%$ of global crops are lost to disease [100]. Furthermore, outbreaks of pests and diseases are expected to increase in the future [101]. Much of the current pest control measures, particularly in developed countries, are based on the application of chemical pesticides to crops. In the USA alone, USD 11 billion was spent on 480 million pounds of pesticides in 2008 [102]. Similarly, in the USA, invasive plant pathogens cause an estimated USD 21 billion in crop losses each year due to diseased crops [103]. However, chemical pest and disease control is not an ecologically sustainable or economically viable solution. Instead, agricultural systems that promote the natural enemies of pests are a sustainable solution: they can reduce yield loss of crops without the negative environmental consequences that result from chemical use and are more economically viable $[104,105]$. In fact, pest control by natural enemies was valued at USD 13 billion per year in the USA [106].

In a meta-analysis by Pumariño et al. [107], pest abundance and plant damage were lower in agroforestry treatments for perennial crops, but annuals were unaffected. This was attributed mostly to the effects of shading by trees, although other studies have attributed this to increased landscape complexity in AFS $[105,108]$. In addition to trees, hedges, boundary plantations, and windbreaks create a physical barrier, especially if pests or pathogens are transported by wind $[109,110]$. A large number of studies have shown that AFS - particularly those with high crop diversity-generally have a higher abundance of natural enemies of pests [104,105,107,108,110-112] and increased competition between pest and non-pest species [108,112]. In addition to reducing pests, AFS have been shown to reduce the environmental effects of pesticides. Pesticide runoff is lower in AFS, and microbial populations in these systems can break down pesticides [113].

Chaplin et al. [104] found that despite the increase in natural enemies, pest abundance and plant damage showed no relationship to landscape complexity such as AFS rather than monocultures. Some studies have also reported fewer herbivores and less crop damage in AFS [111]. However, the data are limited; for example, in one meta-analysis $>80 \%$ of papers were on just two crop types [107]. More diverse research is required to get a better understanding of the effects of different AFS on pests, particularly in temperate zones [114]. Moreover, Iverson et al. [115] suggested that appropriate AFS management is key in providing a "win-win" relationship between crop yield and biocontrol; this is not fully taken into account in most studies. Smith, Pearce and Wolfe [112] suggested that good AFS management can involve strategies such as providing sources of adult parasitoid food; providing sites for mating, oviposition and resting; ensuring intermittent distribution of host plants, thus making it harder for pests to find the plants; using "trap-crop" species protecting other crops from herbivore attack; and using plants acting as a repellent to the herbivore [112]. Stamps and Linit [108] 
and Iverson et al. [115] agreed that decreased host plant apparency may have beneficial effects for pest management.

Although there is evidence to suggest that plant diseases were significantly reduced by agroforestry [107,109], far less research has been carried out investigating the effects on plant diseases of AFS compared to plant pests. In a meta-analysis on the effects of AFS on pests and diseases by Pumariño et al. [107], out of the 40 studies included, only two papers were on plant disease and both were for tropical AFS. Beule et al. [116] agreed that studies on the effects of AFS on disease control-particularly in temperate zones-are lacking.

As with pests, appropriate management of AFS is essential for disease control. Beule et al. [116] suggested that various methods of diversification of the AFS can suppress plant diseases. These include growing a mixture of crop varieties, crop rotation, intercropping, and alley cropping. This view was supported by Tilman et al. [117], who suggested that modern intensive agro-ecosystems are more vulnerable to crop damage by pests and diseases due to oversimplification of these systems [117]. Like pest management, reducing host plant density can reduce crop disease prevalence, particularly of soil-borne and splash-dispersed pathogens. Soil microbiology can have a positive impact where antagonist organisms can suppress disease $[109,116]$. In addition, higher tree density results in microclimatic effects and reduced wind speed, which can reduce dispersal of pathogens. Studies also found that shading by trees in temperate AFS reduced pest and disease incidence, which led to better disease resilience $[109,118]$. However, in a review of tropical AFS, Schroth et al. [119] found that the intensity of attacks by pests and diseases in these systems varies with the pest or disease and with its ecological requirements.

\subsection{Fire Prevention}

In 2018 alone over 137,000 ha of land was lost in Europe due to wildfires. Of all the recorded fires in Europe, the Middle East, and North Africa, the largest proportion of burnt land was in forest and other wooded land (58\%), followed by other natural land (32\%), agriculture (9\%), and artificial surfaces (1\%) [120]. Thus, wildfires are particularly problematic in forests.

Wildfires require fuel, oxygen, and heat in order to burn and spread. Unmanaged forests typically contain high fuel loads, increasing the risk of large, rapidly spreading wildfires [121]. However, many AFS have adopted a silvopastoral approach, which incorporates heavy thinning and pruning to create "firebreaks". The land is then grazed by livestock to reduce shrub regrowth, and thus limits fire risk by depriving the fire of adequate fuel [121,122]. This is particularly common in Mediterranean countries such as France and Spain and has been adopted for decades in some cases, and some government policies actively encourage this system, such as in Catalonia [122]. In addition, AFS involve the incorporation of litter and deadwood pools and, therefore, a lower litter depth. As a result, there are fewer flammable forests due to a lower burn temperature, lower maximum flame height, and reduced flame propagation [121].

The EU Rural Development Programme recognised that agroforestry reduces fire risk and some measures to promote agroforestry centred around this benefit [32]. However, these policy measures were insufficient: although the measures promoted both afforestation and reforestation, payments covered loss of income for afforestation but not reforestation. Furthermore, no payments were provided to promote agricultural activity after trees were planted, and so most of the forestland was not cleared in order to reduce forest fires [123].

\subsection{Pollination}

Approximately $85 \%$ of flowering plants depend on more than 100,000 animal species-mostly insects-for pollination [124,125]. This is particularly important for agricultural crops, where animal pollinators affect two thirds of the 1500 global crop species and are essential for up to $30 \%$ of all food production [126]. In Europe, $84 \%$ of the 264 crops studied depend on animal pollination to some extent. In a more recent global study, the level of dependence on animal-mediated pollination was 
calculated for 107 crops, where animal pollination was beneficial for two thirds of crops studied. Furthermore, animal pollination was classed as of high or essential importance for over $40 \%$ of the crops studied [127].

Intensively managed agriculture has been recognised as a major cause of loss of global biodiversity [128] due to the conversion of natural systems into agricultural land and agricultural intensification on land already used for agriculture [129]. Animal pollinators are in decline globally, and estimates suggest that up to $40 \%$ of invertebrate pollinators are at risk of extinction [130]. The global annual economic value of insect pollination is approximately EUR 153 billion. This is the equivalent of $9.5 \%$ of the total economic value of the global agricultural output of all food crops for human consumption [131]. Agroforestry systems have a significant role to play in pollination, but very few studies have quantified the role of agroforestry in pollination. One such study quantified and valued pollination at USD $47 \mathrm{ha}^{-1}$ year $^{-1}$ in combined food and energy agroforestry in Denmark [132]. Despite the significant negative impact on the agriculture industry, the decline in pollinators is mainly due to intensive agriculture [133]. Varah et al. [134] stated that conventional farming methods focus on providing just one ecosystem service-productivity_by reducing environmental complexity by growing intensive monocultures with better economies of scale. By focussing on productivity, many other ecosystem services suffer.

Bentrup et al. [135] provided a detailed review of the effect of temperate agroforestry practices and woody plants on insect pollinators and pollination, focussing on the services they provide pollinators. They found that trees are sources of resin for bees and nectar of high nutritional value and sugar content. Similarly, woody species provide early season pollen and nectar and are hosts to important larvae. The varied woodland structure and reduced disturbance in AFS provide sites for ground nesting, cavity nesting, and overwintering. In addition, the lower exposure to pesticides and runoff in AFS reduces the harmful effects to pollinator populations. The findings were supported by a field study of four silvopastoral and two silvoarable AFS in the UK by Potts et al. [133], where butterfly diversity was significantly higher for AFS than for the control plots (agricultural monocultures growing the same crop as the agroforestry treatment but without the trees). A review by Varah et al. [136] found that temperate AFS provide greater pollination service than monocultures: AFS had twice as many solitary bees and hoverflies, and the species richness of solitary bees was approximately 10.5 times greater in AFS.

Models based on a Swiss field experiment predict enhanced wild bee habitat quality (particularly for cavity-nesting species) and tend to predict increased provision of pollination services by wild bees in landscapes with higher proportions of AFS [137]. In addition, a meta-analysis found that despite a higher abundance of pollinators in AFS compared to arable systems, the abundance of natural enemies and pests was $24 \%$ greater, and arthropod herbivore/pest abundance was $25 \%$ lower in AFS, suggesting the issue is more complex than simply understanding the abundance or diversity of pollinators [138].

\section{Opportunities and Challenges for Agroforestry in Europe}

In the EU, approximately 20 million ha of land is occupied by AFS, and the majority (90\%) are silvopastoral systems [32] located in the Mediterranean area [139]. Aertsens, De Nocker and Gobin [25] estimated that there are still 90 million ha of arable land and 50 million ha of pasture land in the EU that have the potential to be used as agroforestry. AFS provide multiple benefits, viz., provision of ecosystem services, product diversity, enhanced biodiversity and mitigation of GHG emissions and climate resilience, and these multiple functionalities $[31,60,140]$ need to be taken into account in assessing the AFS. AFS provide a good compromise between the input-intensive monoculture for high productivity and nature-based or conservation agriculture with lower productivity, for production of food and non-food products. Due to the diversity of crop and tree species in AFS, yields are more stable in cases of adverse climatic conditions [141,142], reducing the risk exposure for the farmers. Further, there is better nutrient cycling due to the complementarity in time and space in resource use between the crop and tree species, enhancing the resource use and cycling [143] within the production 
system. AFS are not without challenges due to various reasons. If AFS need to be optimized for productivity [144], there is a need to balance the crop and tree population, spacing and cropped area in order to optimize the complementarity between the species. There is a need for on-farm demonstrations and robust field-based evidence of AFS in the relevant socioeconomic settings to match the local demand for produce with the supply from the AFS. These activities need to be matched with agriculture advisors to advise the farmers and policy changes in order to influence the policy-making bodies to bring forth and communicate the multiple benefits of AFS from local to global scale. Hence, we highlight some of the key barriers to implementation, including the costs for the implementation of agroforestry systems, lack of financial incentives, marketing, and awareness/education.

\subsection{High Costs for Implementation}

High costs are common barriers to implementation of new farming practices and production techniques [145]. In the last 10-15 years, the EU has provided several voluntary and mandatory policy instruments (Table 1) for financial support to farmers to promote agroforestry implementation [32,146,147]. Low profitability is still a major concern of farmers and farm managers considering implementation of agroforestry $[147,148]$. AFS are labour-intensive and the high cost of labour in Europe can be a considerable deterrent for people considering adopting AFS [149]. Also, complementarity in temporal and spatial nutrient, water, and radiation use amongst the AFS components is the main reason for increased yields, and if not managed well, the competition amongst the AFS components can decrease yields and cause financial risk [22,148]. Garcia de Jalon et al. [19] modelled and valued the environmental impacts of arable, forestry, and agroforestry systems in Europe. They found that AFS were the second most profitable system after arable, where the financial equivalent annual value with grants was EUR $559 \mathrm{ha}^{-1} \mathrm{yr}^{-1}$ for arable and EUR $364 \mathrm{ha}^{-1} \mathrm{yr}^{-1}$ for AFS. The forestry system had a much lower financial equivalent annual value of EUR $194 \mathrm{ha}^{-1} \mathrm{yr}^{-1}$ with grants. However, in a 20-year field study of combined food and energy production systems in Denmark, calculations on agronomic productivity, costs of production, and revenue flows showed that agroforestry systems had higher net present values compared to monocrops [17]. Further, sensitivity analysis was carried out with different discount rates between $0-10 \%$, and agroforestry systems were most insensitive to the discount rate and provided a stable and consistent net present value [17]. This study demonstrated the need for more field-based studies to demystify the notion that agroforestry systems are economically unviable.

Table 1. Overview of EU policy instruments relevant to agroforestry systems (AFS).

\begin{tabular}{cr}
\hline Policy & Relevance to AFS \\
\hline Common Agricultural Policy (CAP) & $\begin{array}{c}\text { Payments to farmers fulfilling 13 Statutory Management Requirements related } \\
\text { to environment, climate change, and good agricultural condition land. }\end{array}$ \\
\hline $\begin{array}{c}\text { European Biodiversity Strategy to 2020 } \\
\text { Natura 2000-Habitats and } \\
\text { Birds Directives }\end{array}$ & $\begin{array}{c}\text { Aims to halt deterioration and improve the status of species and habitats } \\
\text { covered by EU nature legislation. Linked to CAP and Natura 2000. }\end{array}$ \\
\hline $\begin{array}{c}\text { Aims to protect threatened species and associated habitats. Network of special } \\
\text { protection areas (SPAs) and sites of Community importance (SCIs). Several EU } \\
\text { funds available. }\end{array}$ \\
$\begin{array}{c}\text { Buroad strategy involving many sectors. One objective is to manage natural } \\
\text { Development } \\
\text { Programme (ECCP) }\end{array}$ & $\begin{array}{c}\text { EU strategy to implement the Kyoto Protocol. Measures to improve energy } \\
\text { efficiency and reduce greenhouse gas emissions. }\end{array}$ \\
\hline European Forest Strategy & Aims to ensure sustainable and balanced forest management. \\
\hline
\end{tabular}

\subsection{Inadequate Financial Incentives}

Financial incentives as compensation for provision of ecosystem services from agroforestry are lacking [148]. Payment for ecosystem services is an approach where land stewards such as farmers receive compensation for protecting and restoring ecosystems [150]. Although the EU promotes agroforestry through Pillars I and II of the Common Agricultural Policy (CAP, Table 1), this applies 
only for establishing new AFS and not those already existing [147], a disincentive to maintaining the AFS for those already practising AFS. Furthermore, the EU Emission Trading system does not currently allow trading with carbon credits for land-use or forestry systems [151]. Thus, farmers cannot benefit from selling carbon credits [151] despite the high C sequestration potential of AFS [25,37]. Subsidies and payments for ecosystem services to landowners who already practice agroforestry might mitigate some of the financial risk and encourage farmers and farm managers to maintain AFS in the long term [147].

Of the 13 Statutory Management Requirements under CAP, the first four-protection of water against pollution caused by nitrates; conservation of wild birds; conservation of natural habitats and of wild flora and fauna; and food and feed law [32] — are most relevant to AFS. The Natura 2000 sites are supported through the CAP Pillars 1 and 2, and other EU funds such as the Programme for the Environment and Climate Action and European Structural Funds, viz., Regional Development Fund, Cohesion Fund, and Social Fund [32]. Because of the multifunctional benefits of AFS, AFS are potential candidates to meet several national- and EU-level agricultural policy measures, viz., Nitrate Directive, Water Framework Directive, Greening Measures, Birds and Habitat Directive, Agri-Environmental Schemes, and EU2030 Climate and Energy Framework. Recognizing the role of AFS in meeting these measures can provide a significant boost to adoption of AFS by the farmers, which will bring them economic benefits in the short run and environmental benefits at the EU and global scale [152].

\subsection{Products and Marketing}

Agroforestry produces a diversity of food and non-food products, providing multiple income streams for the farming households or farm manager. This diversity contributes to stable incomes as loss in market value of one product can be compensated by better prices of other products. AFS can provide products such as timber, crops, fruits, nuts, mushrooms, forages, livestock, biomass, Christmas trees, and herbal medicine [113]. Moreover, Wilson and Lovell [113] stated that "a diverse portfolio of products would allow revenue streams to be spread out over the short-term (crops, forage, livestock, mushrooms, certain fruits like currants), medium-term (nuts, fruits such as apples or persimmons, biomass, medicinal plants), and long-term (lumber, increased property value)". Income stability is an insurance against complete loss of income from monoculture with adverse climatic conditions, which is a clear benefit from adoption of agroforestry [17]. Although the complexity of managing AFS is a concern, the diversity of produce is seen by landowners as a benefit of land conversion to AFS, as long as these are financially viable $[19,22,153]$. However, in a survey of landowners and professionals, the lack of markets and lack of market information were the second highest concerns when considering adoption to AFS [154].

High quality products that have traditionally been products of AFS are of particularly high value, for example, Iberian pig ham from Iberian dehesas or reindeer meat in the boreal forest and subarctic tundra zone $[88,155]$, and so landowners should focus on more marketable goods such as these. New needs for natural and high quality products derived from AFS need also to be explored, such as tannins for tanning leather and antioxidants or gluten-free flours [156]. Increasing the portfolio of AFS products, coupled with improved marketing of agroforestry products, [147] is essential. Increased awareness amongst the general public can create incentives for consumers to pay premium prices for agroforestry products and thus provide further incentives for farmers and farm managers [22,147]. For example, certification schemes, such as that of the Rainforest Alliance, have been demonstrated to improve the financial stability of farmers who adopted AFS with shaded coffee plantations in Latin America, which increased coffee yields and provided additional profit [157]. Similar schemes for agroforestry products from Europe might increase awareness amongst the public and provide a potential financial incentive for farmers to adopt AFS. 


\subsection{Education and Awareness}

Many traditional AFS in Europe disappeared in the 20th century due to intensification and mechanisation of agriculture [33], and the disappearance of these traditional systems in Europe resulted in a loss of the knowledge base amongst farmers [139]. This lack of knowledge and advisory service support in the implementation and management of agroforestry systems is a significant barrier to implementation [158]. The choice of tree and crop species and knowledge of their complementarity in resource use influence the profitability of AFS [50], and education and information sharing can be useful in helping farmers choose species that together enhance yields without compromising the main crop $[50,147,148]$. For example, there is an increasing demand for high quality hardwood timber production in Europe [149], which could pose a potential opportunity for profit from adding trees to agricultural lands. Education programmes and exchange opportunities amongst farmers can be useful tools to achieve successful implementation of profitable AFS [147]. Currently, awareness amongst farmers of the benefits of agroforestry is lacking and to overcome the barriers to implementation of AFS in Europe, raising awareness and experiential learning through exchange of experiences amongst farmers and the general public is necessary [22].

\subsection{Field Demonstrations}

Local dissemination activities may consist of activities such as workshops, role-play activities, and focus groups, although the most promising dissemination activity is the use of field demonstrations. Among other challenges, field demonstrations on agroforestry systems are very few and scattered. Hence, there is a clear need to augment the robust scientific evidence on the multiple benefits of agroforestry with on-the-ground demonstrations. The demonstrations can serve as the training platform for the farmers, advisory services, and policy-making bodies and to teach students in the real environments about the multifunctionality of agroforestry systems. In such demonstration sites, training of trainers courses can be organized to provide insights into the costs and revenues generated and preparation of business plans, in order to convince the current and the potential farmers of the economics of agroforestry adoption and its beneficial effects on the environment.

When communication - particularly in a multilingual situation-may be an issue, role-play can precede the field demonstration to ensure that those running the demonstration have the appropriate technical knowledge and confidence that are essential to a successful field demonstration. Moreover, the field day can help to identify management problems, confirm accuracy of data that has been collected, ensure that landowners' felt needs are properly addressed, expose landowners to new management options and give them an opportunity to evaluate these, and to select more landowners for future on-site testing/field demonstrations. Thus landowners will have more ownership of the problem and recognise their important role in the overall research and dissemination process. Extension agents, too, own the problem and are taking part in finding the solution [159]. Workman et al. [151] came to similar conclusions: in a survey of landowners and extension professionals, the lack of demonstrations and lack of familiarity with the practices were cited as major obstacles to the adoption of agroforestry practices. Adesina and Chianu [160] found that the limited amount of contact with extension agents (e.g., at demonstration days) was a barrier to AFS implementation for landowners. However, Arbuckle et al. [161] found that only $16 \%$ of AFS landowners had attended a field demonstration in the last two years, whilst double the number of landowners sought advice from a professional in the past two years. Thus, the issue is twofold: (i) only a third of farmers are seeking professional advice on their AFS, and (ii) field demonstrations are not appealing and/or not readily available.

\section{Conclusions}

In Europe, there is a great potential for AFS to improve agronomic productivity, carbon sequestration, nutrient cycling, soil biodiversity, water retention, and pollination; to reduce soil erosion and fire; and to provide recreational and cultural benefits. However, there are several challenges due 
to the high costs of implementation, lack of financial incentives, inadequate product marketing and pricing, lack of awareness and education, and lack of field demonstrations. These challenges need to be addressed in order to encourage farmers to adopt AFS.

Author Contributions: M.S.-N. wrote the preliminary draft of the paper. N.L.J.R. made significant edits to the draft, expanding on original text, adding new sections where necessary and providing many additional references throughout. B.B.G. made significant improvements to the draft and improved the scientific content of the manuscript. All authors have read and agreed to the published version of the manuscript.

Funding: SUSTAINFARM (grant agreement no. 652615) and WATERFARMING (grant agreement no: 689271).

Acknowledgments: The support from SUSTAINFARM (grant agreement no. 652615) and WATERFARMING (grant agreement no: 689271) projects for revision to improve the scientific content of the manuscript is acknowledged.

Conflicts of Interest: The authors declare no conflict of interest.

\section{References}

1. Lal, R. Managing Soils and Ecosystems for Mitigating Anthropogenic Carbon Emissions and Advancing Global Food Security. Bioscience 2010, 60, 708-721. [CrossRef]

2. Ghaley, B.B.; Vesterdal, L.; Porter, J.R. Quantification and valuation of ecosystem services in diverse production systems for informed decision-making. Environ. Sci. Policy 2014, 39, 139-149. [CrossRef]

3. Ghaley, B.B.; Rusu, T.; Sandén, T.; Spiegel, H.; Menta, C.; Visioli, G.; O'Sullivan, L.; Gattin, I.T.; Delgado, A.; Liebig, M.A.; et al. Assessment of Benefits of Conservation Agriculture on Soil Functions in Arable Production Systems in Europe. Sustainability 2018, 10, 794. [CrossRef]

4. Janssens, I.A.; Freibauer, A.; Schlamadinger, B.; Ceulemans, R.; Ciais, P.; Dolman, A.J.; Heimann, M.; Nabuurs, G.-J.; Smith, P.; Valentini, R. The carbon budget of terrestrial ecosystems at country-scale-A European case study. Biogeosci. Discuss. 2005, 1, 167-193. [CrossRef]

5. Blanco-Canqui, H.; Lal, R. Mismanagement of Cultivated Lands. In Principles of Soil Conservation and Management; Springer: Dordrecht, The Netherlands, 2010; p. 10. [CrossRef]

6. Usman, M.; Ibrahim, F.; Oyetola, S.O. Sustainable agriculture in relation to problems of soil degradation and how to amend such soils for optimum crop production in Nigeria. Int. J. Res. Agric. Food Sci. 2018, 4, 1-17.

7. Smith, J.; Pearce, B.D.; Wolfe, M.S. A European perspective for developing modern multifunctional agroforestry systems for sustainable intensification. Renew. Agric. Food Syst. 2012, 27, 323-332. [CrossRef]

8. Ilany, T.; Ashton, M.S.; Montagnini, F.; Martínez, C. Using agroforestry to improve soil fertility: Effects of intercropping on Ilex paraguariensis (yerba mate) plantations with Araucaria angustifolia. Agrofor. Syst. 2010, 80, 399-409. [CrossRef]

9. Mbow, C.; Smith, P.; Skole, D.; Duguma, L.A.; Bustamante, M.M.C. Achieving mitigation and adaptation to climate change through sustainable agroforestry practices in Africa. Curr. Opin. Environ. Sustain. 2014, 6, 8-14. [CrossRef]

10. Mosquera-Losada, M.; Santiago-Freijanes, J.; Rois-Díaz, M.; Moreno, G.; Herder, M.D.; Aldrey-Vázquez, J.; Ferreiro-Domínguez, N.; Pantera, A.; Pisanelli, A.; Rigueiro-Rodríguez, A. Agroforestry in Europe: A land management policy tool to combat climate change. Land Use Policy 2018, 78, 603-613. [CrossRef]

11. Fagerholm, N.; Torralba, M.; Burgess, P.J.; Plieninger, T. A systematic map of ecosystem services assessments around European agroforestry. Ecol. Indic. 2016, 62, 47-65. [CrossRef]

12. McAdam, J.H.; Burgess, P.J.; Graves, A.; Rigueiro-Rodríguez, A. Classifications and Functions of Agroforestry Systems in Europe. In Agroforestry in Europe: Current Status and Future Propspects; Rigueiro-Rodríguez, A., McAdam, J., Mosquera-Losada, M.R., Eds.; Springer: Dordrecht, The Netherlands, 2009; pp. 21-41. [CrossRef]

13. Mead, R.; Willey, R.W. The Concept of a 'Land Equivalent Ratio' and Advantages in Yields from Intercropping. Exp. Agric. 1980, 16, 217-228. [CrossRef]

14. FAO. Guidelines: Land Evaluation for Rainfed Agriculture, Soils Bulletin 55; FAO: Rome, Italy, 1985.

15. Malezieux, E.; Crozat, Y.; Dupraz, C.; Laurans, M.; Makowski, D.; Ozier-Lafontaine, H.; Rapidell, B.; de Tourdonnet, S.; Valentin-Morison, M. Mixing plant species in cropping systems: Concepts, tools and models: A review. Agron. Sustain. Dev. 2009, 29, 43-62. [CrossRef] 
16. Lovell, S.T.; Dupraz, C.; Gold, M.; Jose, S.; Revord, R.; Stanek, E.; Wolz, K.J. Temperate agroforestry research: Considering multifunctional woody polycultures and the design of long-term field trials. Agrofor. Syst. 2017, 92, 1397-1415. [CrossRef]

17. Xu, Y.; Lehmann, L.M.; De Jalón, S.G.; Ghaley, B.B. Assessment of Productivity and Economic Viability of Combined Food and Energy (CFE) Production System in Denmark. Energies 2019, 12, 166. [CrossRef]

18. Lehmann, L.M.; Borzecka-Walker, M.; Żyłowska, K.; Pisanelli, A.; Russo, G.; Ghaley, B.B. Environmental Impact Assessments of Integrated Food and Non-Food Production Systems in Italy and Denmark. Energies 2020, 13, 849. [CrossRef]

19. García De Jalón, S.; Burgess, P.J.; Graves, A.; Moreno, G.; McAdam, J.; Pottier, E.; Novak, S.; Bondesan, V.; Mosquera-Losada, M.; Crous-Duran, J.; et al. How is agroforestry perceived in Europe? An assessment of positive and negative aspects by stakeholders. Agrofor. Syst. 2018, 92, 829-848. [CrossRef]

20. Sereke, F.; Graves, A.R.; Dux, D.; Palma, J.; Herzog, F. Innovative agroecosystem goods and services: Key profitability drivers in Swiss agroforestry. Agron. Sustain. Dev. 2014, 35, 759-770. [CrossRef]

21. Trozzo, K.E.; Munsell, J.F.; Chamberlain, J.L. Landowner interest in multifunctional agroforestry Riparian buffers. Agrofor. Syst. 2014, 88, 619-629. [CrossRef]

22. Rois-Díaz, M.; Lovrić, N.; Lovric, M.; Ferreiro-Domínguez, N.; Mosquera-Losada, M.; Herder, M.D.; Graves, A.; Palma, J.; Paulo, J.A.; Pisanelli, A.; et al. Farmers' reasoning behind the uptake of agroforestry practices: Evidence from multiple case-studies across Europe. Agrofor. Syst. 2017, 92, 811-828. [CrossRef]

23. Hall, C.; Dawson, T.P.; MacDiarmid, J.I.; Matthews, R.; Smith, P. The impact of population growth and climate change on food security in Africa: Looking ahead to 2050. Int. J. Agric. Sustain. 2017, 15, 124-135. [CrossRef]

24. Lal, R. Soil Carbon Sequestration Impacts on Global Climate Change and Food Security. Science 2004, 304, 1623-1627. [CrossRef] [PubMed]

25. Aertsens, J.; De Nocker, L.; Gobin, A. Valuing the carbon sequestration potential for European agriculture. Land Use Policy 2013, 31, 584-594. [CrossRef]

26. Mondelaers, K.; Aertsens, J.; Van Huylenbroeck, G. A meta-analysis of the differences in environmental impacts between organic and conventional farming. Br. Food J. 2009, 111, 1098-1119. [CrossRef]

27. Ghaley, B.B.; Porter, J.R. Ecosystem function and service quantification and valuation in a conventional winter wheat production system with DAISY model in Denmark. Ecosyst. Serv. 2014, 10, 79-83. [CrossRef]

28. Pardon, P.; Reubens, B.; Reheul, D.; Mertens, J.; De Frenne, P.; Coussement, T.; Janssens, P.; Verheyen, K. Trees increase soil organic carbon and nutrient availability in temperate agroforestry systems. Agric. Ecosyst. Environ. 2017, 247, 98-111. [CrossRef]

29. Bambrick, A.D.; Whalen, J.K.; Bradley, R.L.; Cogliastro, A.; Gordon, A.M.; Olivier, A.; Thevathasan, N.V. Spatial heterogeneity of soil organic carbon in tree-based intercropping systems in Quebec and Ontario, Canada. Agrofor. Syst. 2010, 79, 343-353. [CrossRef]

30. Bazrgar, A.; Ng, A.; Coleman, B.; Ashiq, M.W.; Gordon, A.; Thevathasan, N.V. Long-Term Monitoring of Soil Carbon Sequestration in Woody and Herbaceous Bioenergy Crop Production Systems on Marginal Lands in Southern Ontario, Canada. Sustainability 2020, 12, 3901. [CrossRef]

31. Kay, S.; Graves, A.; Palma, J.H.; Moreno, G.; Roces-Díaz, J.V.; Aviron, S.; Chouvardas, D.; Crous-Duran, J.; Ferreiro-Domínguez, N.; De Jalón, S.G.; et al. Agroforestry is paying off-Economic evaluation of ecosystem services in European landscapes with and without agroforestry systems. Ecosyst. Serv. 2019, 36, 100896. [CrossRef]

32. Mosquera-Losada, M.R.; Santiago Freijanes, J.J.; Pisanelli, A.; Rois, M.; Smith, J.; den Herder, M.; Moreno, G.; Malignier, N.; Mirazo, J.; Lamersdorf, N.; et al. Extent and Success of Current Policy Measures to Promote Agroforestry across Europe, Deliverable 8.23 for EU FP7 Research Project: AGFORWARD 613520. 2016. Available online: https://www.agforward.eu/index.php/en/extent-and-success-of-current-policy-measuresto-promote-agroforestry-across-europe.html?file=files/agforward/documents/Deliverable8.23Extent_and_ Success_of_Current_Policy_Measures_8_Dec_2016.pdf (accessed on 25 August 2020).

33. Quinkenstein, A.; Wöllecke, J.; Böhm, C.; Grünewald, H.; Freese, D.; Schneider, B.U.; Hüttl, R.F. Ecological benefits of the alley cropping agroforestry system in sensitive regions of Europe. Environ. Sci. Policy 2009, 12, 1112-1121. [CrossRef]

34. Giraldo, C.; Escobar, F.; Chara, J.; Calle, Z. The adoption of silvopastoral systems promotes the recovery of ecological processes regulated by dung beetles in the Colombian Andes. Insect Conserv. Divers. 2010, 4, 115-122. [CrossRef] 
35. Kim, D.-G.; Kirschbaum, M.U.; Beedy, T.L. Carbon sequestration and net emissions of CH4 and N2O under agroforestry: Synthesizing available data and suggestions for future studies. Agric. Ecosyst. Environ. 2016, 226, 65-78. [CrossRef]

36. Negash, M.; Kanninen, M. Modeling biomass and soil carbon sequestration of indigenous agroforestry systems using CO2FIX approach. Agric. Ecosyst. Environ. 2015, 203, 147-155. [CrossRef]

37. Mosquera-Losada, M.R.; Freese, D.; Rigueiro-Rodríguez, A. Carbon Sequestration in European Agroforestry Systems; Springer: Dordrencht, The Netherlands, 2011; pp. 43-59. [CrossRef]

38. Dossa, E.L.; Fernandes, E.C.M.; Reid, W.S.; Ezui, K. Above- and belowground biomass, nutrient and carbon stocks contrasting an open-grown and a shaded coffee plantation. Agrofor. Syst. 2008, 72, 103-115. [CrossRef]

39. Tscharntke, T.; Clough, Y.; Bhagwat, S.A.; Buchori, D.; Faust, H.; Hertel, D.; Holscher, D.; Juhrbandt, J.; Kessler, M.; Perfecto, I.; et al. Multifunctional shade-tree management in tropical agroforestry landscapes-A review. J. of App. Eco. 2011, 48, 619-629. [CrossRef]

40. Nair, P.K.R. Agroforestry Systems and Environmental Quality: Introduction. J. Environ. Qual. 2011, 40, 784-790. [CrossRef] [PubMed]

41. Rivest, D.; Lorente, M.; Olivier, A.; Messier, C. Soil biochemical properties and microbial resilience in agroforestry systems: Effects on wheat growth under controlled drought and flooding conditions. Sci. Total Environ. 2013, 463, 51-60. [CrossRef] [PubMed]

42. Jose, S. Agroforestry for ecosystem services and environmental benefits: An overview. Agrofor. Syst. 2009, 76, 1-10. [CrossRef]

43. Jose, S.; Gillespie, A.; Pallardy, S. Interspecific interactions in temperate agroforestry. Agrofor. Syst. 2004, 61-62, 237-255. [CrossRef]

44. Thevathasan, N.; Gordon, A. Ecology of tree intercropping systems in the North temperate region: Experiences from southern Ontario, Canada. Agrofor. Syst. 2004, 61-62, 257-268. [CrossRef]

45. Zhang, P. The Impact of Nutrient Inputs from Stemflow, Throughfall, and Litterfall in a Tree-Based Temperate Intercrop-Ping System, Southern ON, Canada. Master's Thesis, Department of Environmental Biology, University of Guelph, Guelph, ON, Canada, 1999.

46. Torralba, M.; Fagerholm, N.; Burgess, P.; Moreno, G.; Plieninger, T. Do European agroforestry systems enhance biodiversity and ecosystem services? A meta-analysis. Agric. Ecosyst. Environ. 2016, 230, 150-161. [CrossRef]

47. Swieter, A.; Langhof, M.; Lamerre, J.; Greef, J.M. Long-term yields of oilseed rape and winter wheat in a short rotation alley cropping agroforestry system. Agrofor. Syst. 2018, 93, 1853-1864. [CrossRef]

48. Gao, L.; Xu, H.; Bi, H.; Xi, W.; Bao, B.; Wang, X.; Bi, C.; Chang, Y. Intercropping Competition between Apple Trees and Crops in Agroforestry Systems on the Loess Plateau of China. PLoS ONE 2013, 8, e70739. [CrossRef] [PubMed]

49. Dufour, L.; Metay, A.; Talbot, G.; Dupraz, C. Assessing Light Competition for Cereal Production in Temperate Agroforestry Systems using Experimentation and Crop Modelling. J. Agron. Crop. Sci. 2012, 199, 217-227. [CrossRef]

50. Palma, J.; Graves, A.; Burgess, P.J.; Van Der Werf, W.; Herzog, F. Integrating environmental and economic performance to assess modern silvoarable agroforestry in Europe. Ecol. Econ. 2007, 63, 759-767. [CrossRef]

51. Wagg, C.; Bender, S.F.; Widmer, F.; Van Der Heijden, M.G.A. Soil biodiversity and soil community composition determine ecosystem multifunctionality. Proc. Natl. Acad. Sci. USA 2014, 111, 5266-5270. [CrossRef] [PubMed]

52. Kibblewhite, M.; Ritz, K.; Swift, M. Soil health in agricultural systems. Philos. Trans. R. Soc. B Biol. Sci. 2007, 363, 685-701. [CrossRef] [PubMed]

53. Coleman, D.C.; Crossley, D.; Hendrix, P.F. Fundamentals of Soil Ecology, 2nd ed.; Elsevier BV: Burlington, NJ, USA, 2004.

54. Havlicek, E.; Mitchell, E.A.D. Soils Suppressing Biodiversity. In Interactions in Soil: Promoting Plant Growth; John, D., Jennifer, A.K., Eds.; Springer: Dordrecht, The Netherland, 2014; pp. 95-118.

55. Barrios, E.; Sileshi, G.W.; Shepherd, K.D.; Sinclair, F. Agroforestry and Soil Health: Linking Trees, Soil Biota, and Ecosystem Services. In Soil Ecology and Ecosystem Services; Diana, H.W., Richard, D.B., Valerie, B.-P., Jeffrey, E.H., Hefin, J.T., Eds.; Oxford University Press (OUP): Oxford, UK, 2012.

56. Udawatta, R.P.; Kremer, R.J.; Adamson, B.W.; Anderson, S.H. Variations in soil aggregate stability and enzyme activities in a temperate agroforestry practice. Appl. Soil Ecol. 2008, 39, 153-160. [CrossRef] 
57. Lacombe, S.; Bradley, R.L.; Hamel, C.; Beaulieu, C. Do tree-based intercropping systems increase the diversity and stability of soil microbial communities? Agric. Ecosyst. Environ. 2009, 131, 25-31. [CrossRef]

58. Chifflot, V.; Rivest, D.; Olivier, A.; Cogliastro, A.; Khasa, D. Molecular analysis of arbuscular mycorrhizal community structure and spores distribution in tree-based intercropping and forest systems. Agric. Ecosyst. Environ. 2009, 131, 32-39. [CrossRef]

59. Schädler, M.; Brandl, R.; Kempel, A. "Afterlife" effects of mycorrhization on the decomposition of plant residues. Soil Biol. Biochem. 2010, 42, 521-523. [CrossRef]

60. Marsden, C.; Martin-Chave, A.; Cortet, J.; Hedde, M.; Capowiez, Y. How agroforestry systems influence soil fauna and their functions-A review. Plant Soil 2019, 1-16. [CrossRef]

61. Freedman, A.J.; Tan, B.; Thompson, J.R. Microbial potential for carbon and nutrient cycling in a geogenic supercritical carbon dioxide reservoir. Environ. Microbiol. 2017, 19, 2228-2245. [CrossRef] [PubMed]

62. Dollinger, J.; Jose, S. Agroforestry for soil health. Agrofor. Syst. 2018, 92, 1-7. [CrossRef]

63. Nair, P.K.R.; Buresh, R.J.; Mugendi, D.N.; Latt, C.R. Nutrient cycling in tropical agroforestry systems: Myths and science. In Agroforestry in Sustainable Agricultural Systems; Buck, L.E., Lassoie, J.P., Fernandez, E.C.M., Eds.; CRC Press: Boca Raton, FL, USA, 1999; pp. 1-31. [CrossRef]

64. Barea, J.M.; Pozo, M.J.; Azcón, R.; Azcón-Aguilar, C. Microbial co-operation in the rhizosphere. J. Exp. Bot. 2005, 56, 1761-1778. [CrossRef]

65. De Araújo, A.S.F.; Leite, L.F.C.; Iwata, B.D.F.; Lira, M.D.A.; Xavier, G.R.; Figueiredo, M.D.V.B. Microbiological process in agroforestry systems. A review. Agron. Sustain. Dev. 2011, 32, 215-226. [CrossRef]

66. Bainard, L.D.; Klironomos, J.N.; Gordon, A.M. Arbuscular mycorrhizal fungi in tree-based intercropping systems: A review of their abundance and diversity. Pedobiologia 2011, 54, 57-61. [CrossRef]

67. Rintoul, N. Arbuscular mycorrhizal associations in plant nutrition and health. CAB Rev. Perspect. Agric. Veter-Sci. Nutr. Nat. Resour. 2016, 11, 1-16. [CrossRef]

68. Muchane, M.N.; Sileshi, G.W.; Gripenberg, S.; Jonsson, M.; Pumariño, L.; Barrios, E. Agroforestry boosts soil health in the humid and sub-humid tropics: A meta-analysis. Agric. Ecosyst. Environ. 2020, 295, 106899. [CrossRef]

69. Xu, X.; Thornton, P.E.; Post, W.M. A global analysis of soil microbial biomass carbon, nitrogen and phosphorus in terrestrial ecosystems. Glob. Ecol. Biogeogr. 2012, 22, 737-749. [CrossRef]

70. Cardinael, R.; Hoeffner, K.; Chenu, C.; Chevallier, T.; Béral, C.; Dewisme, A.; Cluzeau, D. Spatial variation of earthworm communities and soil organic carbon in temperate agroforestry. Biol. Fertil. Soils 2018, 55, 171-183. [CrossRef]

71. Price, G.W.; Gordon, A.M. Spatial and temporal distribution of earthworms in a temperate intercropping system in southern Ontario, Canada. Agrofor. Syst. 1998, 44, 141-149. [CrossRef]

72. Mupeyo, B.; Barry, T.; Pomroy, W.E.; Ramírez-Restrepo, C.; Lopez-Villalobos, N.; Pernthaner, A. Effects of feeding willow (Salix spp.) upon death of established parasites and parasite fecundity. Anim. Feed Sci. Technol. 2011, 164, 8-20. [CrossRef]

73. Banerjee, S.; Baah-Acheamfour, M.; Carlyle, C.N.; Bissett, A.; Richardson, A.E.; Siddique, T.; Bork, E.W.; Chang, S.X. Determinants of bacterial communities in Canadian agroforestry systems. Environ. Microbiol. 2015, 18, 1805-1816. [CrossRef] [PubMed]

74. Beuschel, R.; Piepho, H.-P.; Joergensen, R.G.; Wachendorf, C. Correction to: Similar spatial patterns of soil quality indicators in three poplar-based silvo-arable alley cropping systems in Germany. Biol. Fertil. Soils 2018, 55, 15-16. [CrossRef]

75. Beule, L.; Corre, M.D.; Schmidt, M.; Göbel, L.; Veldkamp, E.; Karlovsky, P. Conversion of monoculture cropland and open grassland to agroforestry alters the abundance of soil bacteria, fungi and soil-N-cycling genes. PLoS ONE 2019, 14, e218779. [CrossRef]

76. Dosskey, M.G. Toward Quantifying Water Pollution Abatement in Response to Installing Buffers on Crop Land. Environ. Manag. 2001, 28, 577-598. [CrossRef]

77. Udawatta, R.P.; Krstansky, J.J.; Henderson, G.S.; Garrett, H.E. Agroforestry Practices, Runoff, and Nutrient Loss. J. Environ. Qual. 2002, 31, 1214-1225. [CrossRef]

78. Udawatta, R.P.; Garrett, H.E.; Kallenbach, R.L. Agroforestry and grass buffer effects on water quality in grazed pastures. Agrofor. Syst. 2010, 79, 81-87. [CrossRef] 
79. Sepúlveda, R.B.; Carrillo, A.A. Soil erosion and erosion thresholds in an agroforestry system of coffee (Coffea arabica) and mixed shade trees (Inga spp. and Musa spp.) in Northern Nicaragua. Agric. Ecosyst. Environ. 2015, 210, 25-35. [CrossRef]

80. Mutegi, J.K.; Mugendi, D.N.; Verchot, L.V.; Kung'U, J.B. Combining napier grass with leguminous shrubs in contour hedgerows controls soil erosion without competing with crops. Agrofor. Syst. 2008, 74, 37-49. [CrossRef]

81. Carroll, Z.; Bird, S.; Emmett, B.; Reynolds, B.; Sinclair, F. Can tree shelterbelts on agricultural land reduce flood risk? Soil Use Manag. 2006, 20, 357-359. [CrossRef]

82. Nair, P.K.R.; Garrity, D. Agroforestry—The Future of Global Land Use; Springer: Dordrecht, The Netherlands, 2012.

83. Lin, B.B. The role of agroforestry in reducing water loss through soil evaporation and crop transpiration in coffee agroecosystems. Agric. For. Meteorol. 2010, 150, 510-518. [CrossRef]

84. Sajjapongse, A.; Zhu, Q.; Chen, Y.; Wang, H. Development of sustainable agriculture on sloping lands in China. In Proceedings of the 12th ISCO Conference, Bejing, China, 26-31 May 2002; pp. 335-341.

85. Budelman, A. The performance of selected leaf mulches in temperature reduction and moisture conservation in the upper soil stratum. Agrofor. Syst. 1989, 8, 53-66. [CrossRef]

86. Schwendenmann, L.; Veldkamp, E.; Moser, G.; Hölscher, D.; Köhler, M.; Clough, Y.; Anas, I.; Djajakirana, G.; Erasmi, S.; Hertel, D.; et al. Effects of an experimental drought on the functioning of a cacao agroforestry system, Sulawesi, Indonesia. Glob. Chang. Biol. 2010, 16, 1515-1530. [CrossRef]

87. Moberg, F. Jordbruket vid ett Vägskäl: Hur får vi Maten och Planetens Resurser att Räcka Till Alla? Svenska Sammanfattning av Studien IAASTD. 2011. Available online: https:/www.naturskyddsforeningen.se/sites/ default/files/dokument-media/jordbruket_vid_ett_vagskal_-_iaastd.pdf (accessed on 25 August 2020).

88. Moreno, G.; Aviron, S.; Berg, S.; Crous-Duran, J.; Franca, A.; De Jalón, S.G.; Hartel, T.; Mirck, J.; Pantera, A.; Palma, J.; et al. Agroforestry systems of high nature and cultural value in Europe: Provision of commercial goods and other ecosystem services. Agrofor. Syst. 2017, 92, 877-891. [CrossRef]

89. Ispikoudis, I.; Sioliou, K.M. Cultural aspects of silvopastoral systems. In Silvopastoralism and Sustainable Management; Mosquera-Losada, M.R., McAdam, J., Rigueiro-Rodríguez, A., Eds.; CABI Publishing: Wallingford, CT, USA, 2005. [CrossRef]

90. Papanastasis, V.P.; Mantzanas, K.; Dini-Papanastasi, O.; Ispikoudis, I. Traditional Agroforestry Systems and Their Evolution in Greece. In Advances in Agroforestry; Rigueiro-Rodríguez, A., McAdam, J., Mosquera-Losada, M.R., Eds.; Springer: Berlin, Germany, 2008; pp. 89-109. [CrossRef]

91. Vera, F.W.M. Grazing Ecology and Forest History; CABI: Wallingford, UK, 2000.

92. Barbieri, C.; Valdivia, C. Recreation and agroforestry: Examining new dimensions of multifunctionality in family farms. J. Rural Stud. 2010, 26, 465-473. [CrossRef]

93. Pardini, A. Agroforestry Systems in Italy: Traditions Towards Modern Management. In Advances in Agroforestry; Rigueiro-Rodróguez, A., McAdam, J., Mosquera-Losada, M.R., Eds.; Springer: Dordrecht, The Netherlands, 2009; Volume 6, pp. 255-267.

94. Smith, J. Agroforestry: Reconciling Production with Protection of the Environment; The Organic Research Centre: Berkshire, MA, USA, 2010.

95. Mäntymaa, E.; Ovaskainen, V.; Juutinen, A.; Tyrväinen, L. Integrating nature-based tourism and forestry in private lands under heterogeneous visitor preferences for forest attributes. J. Environ. Plan. Manag. 2017, 61, 724-746. [CrossRef]

96. Pantera, A.; Papadopoulos, A.; Papanastasis, V.P. Valonia oak agroforestry systems in Greece: An overview. Agrofor. Syst. 2018, 92, 921-931. [CrossRef]

97. Dudek, T. Influence of selected features of forests on forest landscape aesthetic value-Example of se poland. J. Environ. Eng. Landsc. Manag. 2018, 26, 275-284. [CrossRef]

98. Isted, R. Wood pasture and parkland; overlooked jewels of the English countryside. In S Silvopastoralism and Sustainable Management Mosquera-Losada; Rigueiro-Rodríguez, M.R., McAdam, A.J., Eds.; CABI Publishing: Wallingford, CT, USA, 2005. [CrossRef]

99. Pimentel, D.; Acquay, H.; Biltonen, M.; Rice, P.; Silva, M.; Nelson, J.; Lipner, V.; Giordano, S.; Horowitz, A.; D'Amore, M. Environmental and economic costs of pesticide use. BioScience 1992, 42, 750-760. [CrossRef]

100. Savary, S.; Ficke, A.; Aubertot, J.-N.; Hollier, C. Crop losses due to diseases and their implications for global food production losses and food security. Food Secur. 2012, 4, 519-537. [CrossRef] 
101. Frison, E.A.; Cherfas, J.; Hodgkin, T. Agricultural Biodiversity Is Essential for a Sustainable Improvement in Food and Nutrition Security. Sustainability 2011, 3, 238-253. [CrossRef]

102. Fernandez-Cornejo, J.; Nehring, R.F.; Sinha, E.N.; Grube, A.; Vialou, A. Assessing Recent Trends in Pesticide Use in US Agriculture. In Proceedings of the Annual Meeting of the Agricultural and Applied Economics Association (AAEA), Milwaukee, WI, USA, 26-28 July 2009.

103. Rossman, A.Y. The impact of invasive fungi on agricultural ecosystems in the United States. Biol. Invasions 2008, 11, 97-107. [CrossRef]

104. Chaplin, R.E.; O’Rourke, M.E.; Blitzer, E.J.; Kremen, C. A meta-analysis of crop pest and natural enemy response to landscape complexity. Ecol. Lett. 2011, 14, 922-932. [CrossRef] [PubMed]

105. Bianchi, F.; Booij, C.; Tscharntke, T. Sustainable pest regulation in agricultural landscapes: A review on landscape composition, biodiversity and natural pest control. Proc. R. Soc. B Biol. Sci. 2006, 273, 1715-1727. [CrossRef] [PubMed]

106. Losey, J.E.; Vaughan, M. The Economic Value of Ecological Services Provided by Insects. Bioscience 2006, 56, 311. [CrossRef]

107. Pumariño, L.; Sileshi, G.W.; Gripenberg, S.; Kaartinen, R.; Barrios, E.; Muchane, M.N.; Midega, C.; Jonsson, M. Effects of agroforestry on pest, disease and weed control: A meta-analysis. Basic Appl. Ecol. 2015, 16, 573-582. [CrossRef]

108. Stamps, W.T.; Linit, M.J. Plant diversity and arthropod communities: Implications for temperate agroforestry. Agrofor. Syst. 1997, 39, 73-89. [CrossRef]

109. Ratnadass, A.; Fernandes, P.; Avelino, J.; Habib, R. Plant species diversity for sustainable management of crop pests and diseases in agroecosystems: A review. Agron. Sustain. Dev. 2011, 32, 273-303. [CrossRef]

110. Sileshi, G.; Schroth, G.; Rao, M.; Girma, H. Weeds, Diseases, Insect Pests, and Tri-Trophic Interactions in Tropical Agroforestry. In Ecological Basis of Agroforestry; Batish, D.R., Kohli, R.K., Jose, S., Singh, H.P., Eds.; CRC Press: London, UK, 2008; pp. 73-94.

111. Letourneau, D.K.; Armbrecht, I.; Rivera, B.S.; Montoya-Lerma, J.; Carmona, E.J.; Daza, M.C.; Escobar-Ramírez, S.; Galindo, V.; Gutiérrez, C.; López, S.; et al. Does plant diversity benefit agroecosystems? A synthetic review. Ecol. Appl. 2011, 21, 9-21. [CrossRef]

112. Smith, J.; Pearce, B.D.; Wolfe, M.S. Reconciling productivity with protection of the environment: Is temperate agroforestry the answer? Renew. Agric. Food Syst. 2012, 28, 80-92. [CrossRef]

113. Wilson, M.; Lovell, S.T. Agroforestry-The Next Step in Sustainable and Resilient Agriculture. Sustainability 2016, 8, 574. [CrossRef]

114. Martin-Chave, A.; Béral, C.; Capowiez, Y. Agroforestry has an impact on nocturnal predation by ground beetles and Opiliones in a temperate organic alley cropping system. Biol. Control 2019, 129, 128-135. [CrossRef]

115. Iverson, A.; Marín, L.E.; Ennis, K.K.; Gonthier, D.J.; Connor-Barrie, B.T.; Remfert, J.L.; Cardinale, B.J.; Perfecto, I. REVIEW: Do polycultures promote win-wins or trade-offs in agricultural ecosystem services? A meta-analysis. J. Appl. Ecol. 2014, 51, 1593-1602. [CrossRef]

116. Beule, L.; Lehtsaar, E.; Rathgeb, A.; Karlovsky, P. Crop Diseases and Mycotoxin Accumulation in Temperate Agroforestry Systems. Sustainability 2019, 11, 2925. [CrossRef]

117. Tilman, D.; Cassman, K.G.; Matson, P.A.; Naylor, R.; Polasky, S. Agricultural sustainability and intensive production practices. Nature 2002, 418,671-677. [CrossRef]

118. Artru, S.; Garré, S.; Dupraz, C.; Hiel, M.-P.; Blitz-Frayret, C.; Lassois, L. Impact of spatio-temporal shade dynamics on wheat growth and yield, perspectives for temperate agroforestry. Eur. J. Agron. 2017, 82, 60-70. [CrossRef]

119. Schroth, G.; Krauss, U.; Gasparotto, L.; Aguilar, J.A.D.; Vohland, K. Pests and diseases in agroforestry systems of the humid tropics. Agrofor. Syst. 2000, 50, 199-241. [CrossRef]

120. San-Miguel-Ayanz, J.; Durrant, T.; Boca, R.; Libertà, G.; Branco, A.; de Rigo, D.; Ferrari, D.; Maianti, P.; Artes Vivancos, T.; Pfeiffer, H.; et al. Forest Fires in Europe, Middle East and North Africa; Publications Office of the European Union: Luxembourg, 2019.

121. Damianidis, C.; Santiago-Freijanes, J.J.; Herder, M.D.; Burgess, P.; Mosquera-Losada, M.R.; Graves, A.; Papadopoulos, A.; Pisanelli, A.; Camilli, F.; Rois-Díaz, M.; et al. Agroforestry as a sustainable land use option to reduce wildfires risk in European Mediterranean areas. Agrofor. Syst. 2020, 1-11. [CrossRef] 
122. Dupraz, C.; Lawson, G.J.; Lamersdorf, N.; Papanastasis, V.P.; Rosati, A.; Ruiz-Mirazo, J. Temperate agroforestry: The European way. In Temperate Agroforestry Systems, 2nd ed; Gordon, A.M., Newman, S.M., Coleman, B., Eds.; CABI: Wallingford, UK, 2018; pp. 98-152.

123. Santiago-Freijanes, J.; Pisanelli, A.; Rois-Díaz, M.; Aldrey-Vázquez, J.; Rigueiro-Rodríguez, A.; Pantera, A.; Vityi, A.; Lojka, B.; Ferreiro-Domínguez, N.; Mosquera-Losada, M. Agroforestry development in Europe: Policy issues. Land Use Policy 2018, 76, 144-156. [CrossRef]

124. Ingram, M.; Nabhan, G.C.; Buchmann, S.L. Impending pollination crisis threatens biodiversity and agriculture. Tropine 1996, 7, 1 .

125. Ollerton, J.; Winfree, R.; Tarrant, S. How many flowering plants are pollinated by animals? Oikos 2011, 120, 321-326. [CrossRef]

126. Kremen, C.; Williams, N.M.; Thorp, R.W. Crop pollination from native bees at risk from agricultural intensification. Proc. Natl. Acad. Sci. USA 2002, 99, 16812-16816. [CrossRef] [PubMed]

127. Klein, A.; E Vaissière, B.; Cane, J.H.; Steffan-Dewenter, I.; Cunningham, S.A.; Kremen, C.; Tscharntke, T. Importance of pollinators in changing landscapes for world crops. Proc. R. Soc. B Biol. Sci. 2006, 274, 303-313. [CrossRef] [PubMed]

128. Ormerod, S.J.; Marshall, E.; Kerby, G.; Rushton, S. Meeting the ecological challenges of agricultural change: Editors' introduction. J. Appl. Ecol. 2003, 40, 939-946. [CrossRef]

129. Attwood, S.J.; Maron, M.; House, A.P.N.; Zammit, C. Do arthropod assemblages display globally consistent responses to intensified agricultural land use and management? Glob. Ecol. Biogeogr. 2008, 17, 585-599. [CrossRef]

130. IPBES. The Assessment Report of the Intergovernmental Science-Policy Platform on Biodiversity and Ecosystem Services on Pollinators, Pollination and Food Production; Potts, S.G., Imperatriz-Fonseca, V.L., Ngo, H.T., Eds.; Secretariat of the Intergovernmental Science-Policy Platform on Biodiversity and Ecosystem Services: Bonn, Germany, 2016. [CrossRef]

131. Gallai, N.; Salles, J.-M.; Settele, J.; Vaissière, B.E. Economic valuation of the vulnerability of world agriculture confronted with pollinator decline. Ecol. Econ. 2009, 68, 810-821. [CrossRef]

132. Costanza, R.; D’Arge, R.; De Groot, R.; Farber, S.; Grasso, M.; Hannon, B.; Limburg, K.; Naeem, S.; O’Neill, R.V.; Paruelo, J.; et al. The value of the world's ecosystem services and natural capital. Nature 1997, 387, $253-260$. [CrossRef]

133. Potts, S.G.; Biesmeijer, J.C.; Kremen, C.; Neumann, P.; Schweiger, O.; Kunin, W.E. Global pollinator declines: Trends, impacts and drivers. Trends Ecol. Evol. 2010, 25, 345-353. [CrossRef]

134. Varah, A.; Jones, H.; Smith, J.; Potts, S.G. Enhanced biodiversity and pollination in UK agroforestry systems. J. Sci. Food Agric. 2013, 93, 2073-2075. [CrossRef]

135. Bentrup, G.; Hopwood, J.; Adamson, N.L.; Vaughan, M. Temperate Agroforestry Systems and Insect Pollinators: A Review. Forests 2019, 10, 981. [CrossRef]

136. Varah, A.; Jones, H.; Smith, J.; Potts, S.G. Temperate agroforestry systems provide greater pollination service than monoculture. Agric. Ecosyst. Environ. 2020, 301, 107031. [CrossRef]

137. Kay, S.; Kühn, E.; Albrecht, M.; Sutter, L.; Szerencsits, E.; Herzog, F. Agroforestry can enhance foraging and nesting resources for pollinators with focus on solitary bees at the landscape scale. Agrofor. Syst. 2020, 94, 379-387. [CrossRef]

138. Staton, T.; Walters, R.J.; Smith, J.; Girling, R. Evaluating the effects of integrating trees into temperate arable systems on pest control and pollination. Agric. Syst. 2019, 176, 102676. [CrossRef]

139. Mosquera-Losada, M.; Moreno, G.; Pardini, A.; McAdam, J.H.; Papanastasis, V.; Burgess, P.J.; Lamersdorf, N.; Castro, M.; Liagre, F.; Rigueiro-Rodríguez, A. Past, Present and Future of Agroforestry Systems in Europe. In Advances in Agroforestry; Nair, P., Garrity, D., Eds.; Springer: Dordrencht, The Netherlands, 2012; Volume 9 , pp. 285-312.

140. Marais, Z.E.; Baker, T.; O'Grady, A.P.; England, J.R.; Tinch, D.; Hunt, M.A. A Natural Capital Approach to Agroforestry Decision-Making at the Farm Scale. Forest 2019, 10, 980. [CrossRef]

141. Ofori, D.; Gyau, A.; Dawson, I.K.; Asaah, E.; Tchoundjeu, Z.; Jamnadass, R. Developing more productive African agroforestry systems and improving food and nutritional security through tree domestication. Curr. Opin. Environ. Sustain. 2014, 6, 123-127. [CrossRef]

142. Mantino, A.; Volpi, I.; Micci, M.; Pecchioni, G.; Bosco, S.; Dragoni, F.; Mele, M.; Ragaglini, G. Effect of Tree Presence and Soil Characteristics on Soybean Yield and Quality in an Innovative Alley-Cropping System. Agronomy 2019, 10, 52. [CrossRef] 
143. Isaac, M.E.; Borden, K.A. Nutrient acquisition strategies in agroforestry systems. Plant Soil 2019, 444, 1-19. [CrossRef]

144. Rahman, S.A.; Baral, H.; Sharma, R.; Samsudin, Y.B.; Meyer, M.; Lo, M.; Artati, Y.; Simamora, T.I.; Andini, S.; Leksono, B.; et al. Integrating bioenergy and food production on degraded landscapes in Indonesia for improved socioeconomic and environmental outcomes. Food Energy Secur. 2019, 8, e00165. [CrossRef]

145. Long, T.B.; Blok, V.; Coninx, I. Barriers to the adoption and diffusion of technological innovations for climate-smart agriculture in Europe: Evidence from the Netherlands, France, Switzerland and Italy. J. Clean. Prod. 2016, 112, 9-21. [CrossRef]

146. Panagos, P.; Imeson, A.; Meusburger, K.; Borrelli, P.; Poesen, J.; Alewell, C. Soil Conservation in Europe: Wish or Reality? Land Degrad. Dev. 2016, 27, 1547-1551. [CrossRef]

147. Hernández-Morcillo, M.; Burgess, P.J.; Mirck, J.; Pantera, A.; Plieninger, T. Scanning agroforestry-based solutions for climate change mitigation and adaptation in Europe. Environ. Sci. Policy 2018, 80, 44-52. [CrossRef]

148. Graves, A.R.; Burgess, P.J.; Liagre, F.; Dupraz, C. Farmer perception of benefits, constraints and opportunities for silvoarable systems. Outlook Agric. 2017, 46, 74-83. [CrossRef]

149. Eichhorn, M.P.; Paris, P.; Herzog, F.; Incoll, L.D.; Liagre, F.; Mantzanas, K.; Mayus, M.; Moreno, G.; Papanastasis, V.P.; Pilbeam, D.J.; et al. Silvoarable Systems in Europe-Past, Present and Future Prospects. Agrofor. Syst. 2006, 67, 29-50. [CrossRef]

150. Milder, J.C.; Scherr, S.J.; Bracer, C. Trends and Future Potential of Payment for Ecosystem Services to Alleviate Rural Poverty in Developing Countries. Ecol. Soc. 2010, 15, 6. [CrossRef]

151. Van Vooren, L.; Reubens, B.; Broekx, S.; Pardon, P.; Reheul, D.; Van Winsen, F.; Verheyen, K.; Wauters, E.; Lauwers, L. Greening and producing: An economic assessment framework for integrating trees in cropping systems. Agric. Syst. 2016, 148, 44-57. [CrossRef]

152. Schulte, R.; Bampa, F.; Bardy, M.; Coyle, C.; Creamer, R.E.; Fealy, R.; Gardi, C.; Ghaley, B.B.; Jordan, P.; Laudon, H.; et al. Making the Most of Our Land: Managing Soil Functions from Local to Continental Scale. Front. Environ. Sci. 2015, 3, 1-14. [CrossRef]

153. Graves, A.R.; Burgess, P.J.; Liagre, F.; Pisanelli, A.; Paris, P.; Moreno, G.; Bellido, M.; Mayus, M.; Postma, M.; Schindler, B.; et al. Farmer Perceptions of Silvoarable Systems in Seven European Countries. In Agroforestry in Europe: Current Status and Future Propspects; Rigueiro-Rodríguez, A., McAdam, J., Mosquera-Losada, M.R., Eds.; Springer: Dordrecht, The Netherlands, 2009. [CrossRef]

154. Workman, S.W.; Bannister, M.E.; Nair, P. Agroforestry potential in the southeastern United States: Perceptions of landowners and extension professionals. Agrofor. Syst. 2003, 59, 73-83. [CrossRef]

155. Augère-Granier, M.L. Agroforestry in the European Union. 2020. Available online: https://www.europarl. europa.eu/RegData/etudes/BRIE/2020/651982/EPRS_BRI(2020)651982_EN.pdf (accessed on 25 August 2020).

156. Moreno, G.; Franca, A.; Pnto Correia, M.T.; Godinho, S. Multifunctionality and dynamics of silvopastoral systems. Options Méditerr. 2014, 109, 421-436.

157. Perfecto, I.; VanderMeer, J.; Mas, A.; Soto-Pinto, L. Biodiversity, yield, and shade coffee certification. Ecol. Econ. 2005, 54, 435-446. [CrossRef]

158. Gómez, J.A.; Guzmán, G.; Giráldez, J.V.; Fereres, E. The influence of cover crops and tillage on water and sediment yield, and on nutrient, and organic matter losses in an olive orchard on a sandy loam soil. Soil Tillage Res. 2009, 106, 137-144. [CrossRef]

159. Yamoah, C.F.; Grosz, R. Linking on-station research with on-farm testing: The case of agroforestry and organic matter-based cropping systems for the Rwanda farming systems improvement project. Agroforest. Syst. 1988, 6, 271-281. [CrossRef]

160. Adesina, A.A.; Chianu, J. Determinants of farmers' adoption and adaptation of alley farming technology in Nigeria. Agrofor. Syst. 2002, 55, 99-112. [CrossRef]

161. Arbuckle, J.G.; Valdivia, C.; Raedeke, A.; Green, J.; Rikoon, J.S. Non-operator landowner interest in agroforestry practices in two Missouri watersheds. Agrofor. Syst. 2008, 75, 73-82. [CrossRef]

(C) 2020 by the authors. Licensee MDPI, Basel, Switzerland. This article is an open access article distributed under the terms and conditions of the Creative Commons Attribution (CC BY) license (http://creativecommons.org/licenses/by/4.0/). 